\title{
IDEOLOGIA EM ALOCUÇÕES DO IMPERADOR DO JAPÃO: UMA ANÁLISE CRÍTICA COM BASE EM THOMPSON
}

Raphael dos Santos Miguelez Perez ${ }^{1}$

Resumo: O presente artigo procura mostrar que modos de operação da ideologia podem ser encontrados no discurso de Akihito, Imperador do Japão. Para tal, utiliza-se o arcabouço teórico da Análise Crítica do Discurso, mais precisamente o conceito de ideologia e os modos de operação da ideologia de Thompson. Sendo assim, a análise crítica de alocuções de Akihito mostra que, por mais que atualmente o Imperador do Japão não governe de fato, de acordo com a Constituição vigente desde o pós-guerra, a posição que ocupa como símbolo da nação e da união do povo confere a ele influência sobre esse povo, exercida por meio da ideologia.

Palavras-chave: Imperador do Japão; Akihito; ideologia; Análise Crítica do Discurso; Thompson.

Abstract: The present article aims to show which modes of operation of ideology can be found in the Emperor of Japan Akihito's discourse. For this purpose, Critical Discourse Analysis' theoretical basis is used here, more precisely the concept of ideology and the modes of operation of ideology created by Thompson. In this way, the critical analysis of Akihito' speeches reveals that even if the Emperor of Japan does not rule the country, as stated in the Constitution of Japan, valid since the end of the Second World War, his position as the symbol of the nation and of the union of the people confers him influence over these people, carried out by the ideology.

Key words: Emperor of Japan; Akihito; ideology; Critical Discourse Analysis; Thompson.

\section{Introdução}

O Japão pós-guerra definitivamente passou a fazer parte das relações mundiais, além de se tornar uma das maiores potências, o que lhe traz certas responsabilidades nas decisões que se toma para todo o mundo. Essa monarquia constitucional

1. Mestrando em Linguística da Universidade do Estado do Rio de Janeiro. 
tem como governo um parlamento, conhecido como Dieta, que toma as decisões e governa de fato o país, mas tem também como símbolo da nação um imperador, cargo meramente simbólico no Japão atual, diferente da época pré-guerra, em que o Imperador era considerado uma divindade e tinha poder absoluto.

Com o término da II Guerra, os Estados Unidos dominaram o país e criaram uma nova Constituição, que proibia o Japão de entrar em guerra e de se militarizar, além de tirar do Imperador seus poderes políticos e seu status de divindade, mantendo-o, no entanto, como símbolo da nação e da união do povo japonês.

O presente trabalho busca analisar alocuções do atual Imperador do Japão, Akihito, com o objetivo de verificar que modos de operação da ideologia estão presentes em seu discurso e de que forma a ideologia garante sua influência sobre o povo japonês.

Os textos selecionados são aqueles proferidos em conferências de imprensa, que ocorrem anualmente na ocasião do aniversário do Imperador, bem como em outras ocasiões especiais, como quando das comemorações de dez anos de trono.

Meu interesse enquanto pesquisador por esse material de análise se justifica pela natureza dessa forma de governo pela qual o Japão vem sendo regido desde o término da II Guerra Mundial. Entender o discurso de Akihito, que assume o reinado depois de seu pai, Hirohito, período conturbado devido à participação do país na guerra, nos ajuda a compreender a participação do Japão no mundo e o que significa ser um imperador sem um império de fato, função que tem sua importância, mesmo que simbolicamente, como prevê a Constituição do Japão.

\section{Problemas de Pesquisa}

O Imperador do Japão, embora não possua poder político de fato, conforme designado pela Constituição vigente, acaba por exercer influência sobre o povo japonês devido às atribuições de seu cargo. Sua posição simbólica, como representante do povo japonês, faz dele um modelo nipônico a ser seguido. Assim, podemos compreender que o Imperador do Japão, embora impedido de exercer de fato o poder executivo, exerce alguma influência sobre o povo japonês por meio de modos de operação da ideologia, que ajuda a manter sua posição.

Partindo da conceituação de ideologia de Thompson (2002), esse trabalho objetiva verificar, por meio de alocuções de Akihito, quais os modos de operação da ideologia que podem ser encontrados em seu discurso e de que forma eles ajudam a manter essa instituição, que é o Imperador do Japão.

\section{Corpus de Análise e Metodologia}

O corpus de análise recolhido para este artigo se encontra no website oficial da Casa Imperial do Japão (ver referências), na parte relativa aos discursos dos 
membros da Família Imperial. Optou-se por fazer um recorte das alocuções do Imperador relativo apenas àquelas proferidas em conferências de imprensa, que acontecem frequentemente nas seguintes ocasiões:

1. quando do aniversário do Imperador;

2. a cada dez anos de reinado;

3. quando das visitas diplomáticas ao exterior;

4. um especial realizado quando de seu aniversário de 50 anos de casamento.

Essa escolha se deu por ser nas conferências de imprensa que o Imperador se encontra frente a perguntas mais específicas e variadas a respeito de suas funções, diferente de seus discursos livres, quando não precisa tocar em assuntos que julgue delicados para ele ou sua família. No entanto, por se tratar de um material muito extenso, preferi me ater apenas às perguntas e respostas relativas ao exercício do poder do Imperador, ou seja, àquelas em que ele se encontra obrigado a falar de suas próprias funções e de como ele as vê.

Para tornar a presente pesquisa mais abrangente ao leitor comum, optei por não analisar os discursos originais em japonês, mas suas traduções para o inglês, também disponíveis no website. Importante ressaltar que considero essas traduções como sendo oficiais e representativas da figura do Imperador, uma vez que se encontram na página eletrônica oficial da Família Imperial. O original em japonês, no entanto, servirá em alguns momentos como material para comparação, quando relevante.

O presente corpus de pesquisa apresenta, portanto, os discursos de 1998 e de 2000, quando da comemoração do aniversário do Imperador, bem como os de 1999 e 2009 , quando da comemoração de 10 e de 20 anos de trono, respectivamente.

A análise desse material se dará por meio da aplicação dos modos de operação da ideologia propostos por Thompson (2002).

\section{Fundamentação Teórica}

Thompson (2002) teoriza a respeito de ideologia criando para o termo uma nova acepção. $\mathrm{O}$ autor relê teóricos anteriores que já discutiram a respeito do termo e os divide entre aqueles que possuem uma concepção neutra e aqueles que possuem uma concepção crítica a respeito da ideologia. As concepções neutras de ideologia são aquelas que não possuem um caráter negativo ou pejorativo sobre o termo, não tendo a necessidade de combatê-lo, caso das concepções desenvolvidas por Destutt de Tracy, Lenin, Lukács e Mannheim (o último no que se refere 
à sua conceituação inicial de ideologia). Por sua vez, as concepções críticas são aquelas oferecidas por Napoleão, Marx e Mannheim (em um segundo momento), concepções de ideologia com sentido negativo e passível de crítica.

Sobre sua própria análise da ideologia, Thompson explica:

\begin{abstract}
Procurarei combater o que descrevi como a neutralização do conceito de ideologia. Tentarei formular uma concepção crítica de ideologia, apoiando-me em alguns dos temas implícitos nas concepções anteriores e abandonando outros; procurarei mostrar, ainda, que esta concepção pode oferecer uma base para um enfoque útil e defensável para a análise da ideologia, um enfoque que está orientado para a análise concreta dos fenômenos sócio-históricos, mas que ao mesmo tempo mantém o caráter crítico transmitido a nós pela história do conceito. (Thompson, 2002, p. 77)
\end{abstract}

O autor explica, então, que seu conceito de ideologia está primeiramente preocupado com a forma pela qual as formas simbólicas estão relacionadas com as relações de poder e também com o modo pelo qual o sentido é mobilizado, contribuindo para reforçar pessoas e grupos em posições de poder. Thompson acrescenta que "estudar a ideologia é estudar as maneiras como o sentido serve para estabelecer e sustentar relações de dominação" (Thompson, 2002, p. 78)

Dessa forma, a concepção de ideologia de Thompson se afasta em alguns pontos das outras concepções críticas do termo. Apenas um critério de negatividade é mantido nessa nova releitura: o de sustentação das relações de dominação. No entanto, diferente de Marx, Thompson não considera as relações de classe como sendo a única forma de dominação e subordinação. Ele aponta que relações entre os sexos, entre os grupos étnicos, entre os indivíduos e o estado, entre estados-nação hegemônicos e estados-nação marginalizados, etc., também configuram relações de poder. Além disso, Thompson considera as relações sociais como sendo constituídas por formas simbólicas que mobilizam o sentido. Assim, o sentido pode manter e reproduzir relações de dominação através de um processo de produção e recepção de formas simbólicas. Por formas simbólicas, o autor entende uma gama de formas linguísticas e não-linguísticas que são produzidas por sujeitos e reconhecidas por e entre eles como construtos significativos, ou seja, dotados de sentido. $\mathrm{O}$ autor ainda completa que a dominação se dá quando relações de força ou de poder se dão de forma assimétrica, que é quando certos grupos possuem poder ou influência de forma permanente e em grau significativo.

Em termos mais metodológicos de pesquisa, Thompson cria o que chama de modos gerais de operação da ideologia, dividindo-os em cinco: legitimação, dissimulação, unificação, fragmentação e reificação. É por meio desses modos de operação que o sentido serve para estabelecer e sustentar relações de dominação. Cada um desses cinco modos se subdivide em tantas outras estratégias típicas de construção simbólica. 
O modo de operação da ideologia denominado legitimação mostra como as relações de dominação ganham status de legítimas. Isso se dá por meio de três estratégias. A primeira delas é a racionalização, através da qual se busca legitimar um conjunto de relações por meio da racionalização de uma cadeia de raciocínio. A estratégia conhecida como universalização, por sua vez, busca legitimar interesses específicos tratando-os como se fossem interesses gerais e comuns a todos. O processo de narrativização, terceira estratégia de legitimação, busca justificar algo por meio de uma busca histórica que sirva para tal fim.

O segundo modo de operação da ideologia é a dissimulação, que oculta, nega ou obscurece relações de dominação. Mais três estratégias servem a esse fim. A primeira delas é o deslocamento, que trata determinado termo ou expressão característico de um campo como sendo pertencente a outro campo. Um termo que geralmente estaria relacionado a alguém ou a algo, ao ser usado de forma diferente carrega consigo as conotações positivas ou negativas que estejam nele originalmente. A segunda estratégia é a eufemização, que muda a valoração de alguma ação, relação ou instituição. Algo que é visto como negativo, por exemplo, pode ser aplicado num contexto e de tal forma que pareça o contrário. A última estratégia desse modo de operação é o que se chama de tropo, que trata do uso figurativo da linguagem (inclui a sinédoque, a metonímia e a metáfora).

O modo de unificação, por sua vez, auxilia na construção simbólica de uma identidade coletiva. A padronização (também traduzida como estandardização) utiliza uma forma simbólica como referencial padrão, ou seja, algo compartilhado por todos. É o caso das línguas nacionais, como o japonês, que unifica o povo em torno dessa forma de construção simbólica. A outra estratégia de unificação é a simbolização da unidade, que, conforme sugere o nome, cria símbolos de unidade e de identificação coletiva, como bandeiras, hinos etc.

O quarto modo de operação da ideologia é a fragmentação, que visa segmentar indivíduos e grupos, isolando-os de todo o resto. Essa forma de ideologia se divide em duas estratégias de construção simbólica, sendo a primeira delas a diferenciação. Essa estratégica visa enfatizar a diferença entre os grupos de indivíduos, como caracterizá-los por suas posições sociais, por exemplo, o que cria um estranhamento entre determinado grupo e outro e, consequentemente, os impede de se tornarem um só contra uma forma de poder maior. A estratégia chamada de expurgo do outro amplia essa ideia, mas de forma mais incisiva, uma vez que constrói um inimigo comum a todos, como é o caso dos terroristas islâmicos, tratado pelos EUA como inimigos da paz e do mundo.

O último modo de operação da ideologia é a reificação. Através dela, é possível tratar determinada situação que na realidade é transitória como algo permanente e natural. A estratégia da naturalização trata determinada criação social e histórica como sendo natural e inevitável, o que leva a sua permanência através 
dos tempos. A eternalização, por sua vez, é uma estratégia que esvazia determinados fenômenos sócio-históricos de seu caráter histórico ao apresentá-los como recorrentes e imutáveis. Por fim, a estratégia da nominalização e da passivização busca omitir sujeitos responsáveis por determinada ação, seja nominalizando uma oração, seja tornando-a uma oração na voz passiva, sem indicar o agente da passiva. Essa estratégia é muito utilizada pela mídia, quando diz, por exemplo, "o banimento das importações", em vez de "o Primeiro-Ministro decidiu banir as importações"; ou como em "o suspeito está sendo investigado", no lugar de "os policiais estão investigando o suspeito" (Thompson, 2002, p. 90)

Apresento, então, a seguir, um breve perfil do atual Imperador do Japão, Akihito, passando depois para a análise de suas alocuções.

\section{O Imperador Akihito}

Akihito é filho de Hirohito, este último conhecido como Imperador Shôwa (a palavra shôwa utiliza os ideogramas de "brilhante" e de "harmonia"), figura polêmica que governou o Japão de 1926 a 1989, sendo que em 1947 deixou de ter poder político, com a ocupação do Japão pelos Estados Unidos no pós-guerra. Akihito, atual imperador, reina em um período conhecido como Heisei (a palavra heisei utiliza os ideogramas de "paz" e de "tornar-se"). Sendo assim, depois de sua morte, Akihito será conhecido como Imperador Heisei.

Nascido em 23 de dezembro de 1933, o atual Imperador tornou-se Príncipe Herdeiro em 10 de novembro de 1952 e assumiu o trono como Imperador em 7 de janeiro de 1989, quando da morte de seu pai. Akihito é o símbolo do Estado e da união do povo japonês, desprovido de poderes políticos, conforme indica a Constituição em vigor no Japão desde 1947 Vale ressaltar que, durante o governo de Hirohito, o Imperador era tido, pela Constituição Imperial, como descendente divino e tinha poder absoluto sobre o Estado (a Constituição Imperial foi promulgada com a Restauração Meiji, em 1868, que retirou o poder dos xoguns e o devolveu ao imperador).

Akihito é casado com a Imperatriz Michiko e juntos possuem três filhos: Príncipe Herdeiro Naruhito, Príncipe Akishino e Sayako, esta última tendo perdido o título de princesa por ter se casado com um japonês não pertencente à Família Imperial ${ }^{2}$. Akihito estudou Ciências Políticas na Universidade Gakushuin, em Tóquio, mas nunca chegou a graduar-se. No entanto, o Imperador sempre vem contribuindo com pesquisas acadêmicas na área de Biologia.

2. Como consta no Artigo 12 das Leis da Casa Imperial (The Imperial House Law), se um membro feminino pertencente à Familia Imperial se casa com alguém de fora da Casa Imperial, ele perde seu status real (caso de Sayako). No entanto, o mesmo não ocorre com membros masculinos, que possuem o direito de se casarem com mulheres não pertencentes à Casa Imperial (Artigo 15), caso dos outros dois filhos de Akihito. 
Como representantes do povo, Akihito e sua esposa têm procurado se aproximar cada vez mais dos japoneses, diferentemente dos imperadores anteriores, que sequer eram vistos pela população. O casal já visitou todas as províncias do Japão, prática que procuram ter principalmente quando ocorre algum desastre natural no país, como foi o caso do terremoto de 1995, em Kobe, e do tsunami de março de 2011, que destruiu grande parte da região de Tôhoku e tirou diversas vidas. Além disso, já visitaram também locais afetados na II Guerra Mundial e Akihito muitas vezes já apresentou suas condolências aos países que foram atacados pelo Japão nessa época. Apesar de sua saúde frágil, o Imperador continua fazendo o possível para continuar exercendo as funções que cabem à sua posição.

Nakamura (1992), que estuda sobre o significado do "símbolo", função atribuída ao Imperador na Constituição de 1947, afirma que com a ascensão de Akihito, três deveriam ser suas principais preocupações para que a Família Imperial seja mantida e com a confiança do povo.

Primeiramente, o fato de Akihito, ao ascender ao trono, não ter confirmado a culpa do pai na II Guerra, faz com que ele ignore esse período da história do Japão como se nada houvesse acontecido e, de certa forma, funciona como um desrespeito à Constituição, formulada com base na reflexão sobre os males da guerra. Ele também encoraja o povo a não depender tanto do Imperador e tomar as rédeas no que diz respeito a se comunicar com o mundo baseando-se numa acurada compreensão da história.

Quanto a não convivência entre monarquia e democracia, Nakamura aponta que há aqueles que creem que não é possivel haver uma democracia enquanto houver um Imperador, devendo este ser abolido, assim como há outros que defendem a permanência do Imperador enquanto símbolo para garantir e preservar a união e a cultura do povo nipônico. $\mathrm{O}$ autor acredita que para se ter uma democracia, o necessário é eliminar qualquer tabu relativo ao Imperador e permitir que as pessoas tenham livre opinião sobre o sistema imperial. Ele cita o caso do prefeito de Nagasaki em 88, Motoshima Hitoshi, que depois de afirmar publicamente que acreditava na culpa do Imperador Shôwa na guerra, sofreu um atentado. Se a monarquia não permite a liberdade de expressão, condição de existência da democracia, então o sistema imperial perderá o apoio e o crédito do povo. Outro ponto que comenta seria prever a abdicação e sucessão imperial por uma mulher, itens não previstos na Constituição e essenciais para manter uma democracia.

Sobre a relação do Japão com os outros países, Nakamura comenta que o país se afastou dos outros por causa de seu culto ao Imperador enquanto divindade e por sua postura agressiva na II Guerra. A invasão americana no Japão, no pós-guerra, se deu justamente para desmilitarizar o Japão e impedir que esse tipo de ameaça se concretizasse novamente. Assim, para que o Japão tenha uma boa relação internacional, é preciso que o Imperador não seja usado para propósitos políticos (como afirma ter sido o Imperador Shôwa). 
Alguns desses temas são abordados nas conferências de imprensa por caracterizarem a instituição imperial neste momento da história do Japão. As observações de Nakamura, portanto, são úteis para se ter um panorama bastante elaborado sobre a função do Imperador enquanto símbolo de um país.

\section{Análise}

Como explicado anteriormente, o corpus a ser analisado se encontra em inglês, de acordo com a tradução disponibilizada no website da Casa Imperial.

Primeiramente, nos itens 6.1 e 6.2, serão apresentadas as análises das conferências de imprensa realizadas no aniversário do Imperador nos anos de $1998 \mathrm{e}$ 2000 , respectivamente. Em seguida, nos itens 6.3 e 6.4, seguem as conferências de imprensa realizadas quando da comemoração de 10 e de 20 anos de reinado, nos anos de 1999 e 2009, respectivamente.

\subsection{Conferência de imprensa de 1998, quando do aniversário do Imperador}

PERGUNTA: A decade has passed since the Heisei Era began and it seems to me that the ways in which the Emperor carries out His activities have changed as compared to the Showa Era. From Your own point of view, what things, from which perspective, do You see as changed? Moreover, how do You perceive the expectations of the people and in what way do You intend to respond to them from now on?

RESPOSTA: According to the Constitution of Japan, the Emperor is defined as the symbol of the State and of the unity of the people. Reflecting on such a constitutional definition and on the historv of the Emperors. whose constant aspirations have been for the happiness of the people. I believe that it is the duty of the Emperor to devote himself to the nation and the people. The principle determining the Emperor's activities does not change all that suddenly with the times. Of course, it is a fact that some aspects do change over time. Carrving on the feelings of Emperor Showa. in responding to the needs of the nation and our societv and the expectations of the people, I intend to be with the people in spirit as I fulfill my duties as Emperor.[grifos meus]

Podemos destacar nas perguntas o uso de "You", com inicial maiúscula, indicando respeito pela figura do Imperador. Essa forma de tratamento aparecerá sempre nas perguntas. Verifica-se, então, a estratégia de construção simbólica da diferenciação (fragmentação). Essa mesma estratégia aparecerá em todas as perguntas feitas ao Imperador, como poderemos perceber mais adiante na análise. No original em japonês, os jornalistas utilizam keigo (linguagem honorífica) para se referir ao Imperador, como "gojishin" (no caso, significando "do seu ponto de vista") e "okangae deshô ka" (o que acha?).

$\mathrm{Na}$ resposta do Imperador, verifica-se o uso da narrativização (legitimaçâo) quando ele evoca o passado e repensa a história da Família Imperial e o desejo de felicidade da nação que sempre possuíram. Além disso, verificamos ainda as estraté- 
gias de simbolização da unidade (unificação) e de eternalização (reificação), pois Akihito se refere à população como "our society", englobando todos os membros da Família Imperial e também se incluindo nessa sociedade, além de afirmar que continuará seu reinado seguindo os passos de seu pai, o Imperador Shôwa, eternalizando esse reinado imperial.

\subsection{Conferência de imprensa de 2000, quando do aniversário do Imperador}

PERGUNTA: Your Majesty made a response looking back on this century. You pointed out that many events had taken place. At the same time, the last one hundred years have also been witness to great changes and upheavals in the Imperial Family. How do vou view these changes and upheavals that have taken place over the course of the 20th century, and could you tell us what you consider to be the ideal role for the Imperial Familv facing the 21st century? While Your Majesty has already expressed your thinking on this matter on several occasions, could vou tell us once again vour opinions as the century draws to a close?

RESPOSTA: The first year of this century was the 34th year of the reign of Emperor Meiji, and was also the year in which Emperor Showa was born. By that time, the Imperial Constitution of Japan was already in place, and I think that the role of the Imperial Familv was considered as the one stipulated in the Constitution. Furthermore, the Imperial Family placed great emphasis on exchanges with foreign countries, and the phrase "Totsukuni to mutsumi kawasu..." I"To conduct harmonious exchange with foreign countries..."] frequently occurs in the poems of Emperor Meiji, demonstrating the sentiments embraced by the Emperor. Also, the Anglo-Japanese Alliance was concluded the following year.

When one considers these events, the role of the Imperial Family was considered until the beginning of the Showa era as one of strengthening friendly relations with foreign countries and, on the domestic level, upholding the Constitution. Japan subsequently deviated from this path, thus creating a period where great difficulties continued for Emperor Showa. As I mentioned earlier, the first half of this century was scourged by wars, and this continued right through the early Showa period.

In the postwar period, under the new Constitution, the Imperial Family took on a symbolic role, different from the past, but the feelings of the Imperial Family towards the people remain unchanged. I believe that this sentiment towards the people has remained the same since ancient times for all the successive Emperors. As for the role of the Imperial Family. I consider that, while always bearing in mind its symbolic role, we should seek the most appropriate way to carry out that role. From now on too, I believe that this point will remain unchanged. [grifos meus]

Na pergunta, mais uma vez conferimos o uso da differenciação (fragmentação), embora, por algum motivo, alguns pronomes apareçam com a inicial em minúscula. Podemos perceber também o uso de "Your Majesty", seguindo a tradição formal de se referir a reis e imperadores, o que também se mostra como um recurso de diferenciação. Em japonês, uma característica dessa língua se faz presente, uma vez que não se usa praticamente pronomes pessoais, demonstrando formalidade nos 
verbos através do uso do keigo. Além disso, o termo "Heika" também é utilizado como pronome de tratamento correspondente a "Your Majesty" (Vossa Majestade).

Na resposta, podemos perceber na oração sublinhada no primeiro parágrafo a estratégia de construção simbólica denominada eufemização (dissimulação), uma vez que o Imperador justifica atos de outros imperadores como condicionados pela Constituição, tirando deles a responsabilidade por seus atos.

No segundo parágrafo, o uso de "one" (em japonês, "kono yôna koto kara kangaete") indica uma certa generalização a respeito do que está sendo dito, como se provasse que tal fato é sabido e normalmente entendido por todos. Verifica-se, assim, o recurso da racionalização (legitimação). Além disso, em "great difficulties" (no original, "kurô"), podemos deduzir que o Imperador coloca todo o período de turbulência da II Guerra como sendo um entrave na vida de seu pai, o Imperador Shôwa, não considerando que o próprio possa ter contribuído para a inclusão do Japão nesse evento. Mais uma vez, portanto, identificamos o recurso da eufemização (dissimulação).

No terceiro parágrafo, o Imperador fala da função da Família Imperial e utiliza o pronome "we" (em japonês, o pronome não é utilizado, mas subentende-se que se trate de toda a família uma vez que inicia a oração com "kôshitsu no arikata toshite wa...") para tal, universalizando, assim, sua função, repassando-a aos outros membros de sua família, o que lhe garante, de alguma forma, um poder sobre todos eles. A essa estratégia Thompson dá o nome de universalização (legitimação). $\mathrm{O}$ uso de "remain unchanged", por sua vez, nos fornece uma ideia de eternalização (reificação) do reinado da Família Imperial. Por fim, todo esse terceiro parágrafo é construído por meio de um processo de narrativização (legitimação), visto que o Imperador está sempre buscando justificar o presente com o passado, afirmando seguir o ideal de todos os seus antecessores.

\subsection{Conferência de imprensa de 1999 , quando da comemoração de 10 anos de trono}

PERGUNTA: From the time when Your Maiesties were Crown Prince and Crown Princess You have shown great concern for welfare issues, such as persons with disabilities and the elderly. Since His Majestv's Accession to the Throne in addition to visits to welfare facilities, Your Maiesties have displayed a most caring concern in visiting the sites of disasters and for the reconstruction of the stricken areas. What thoughts do Your Majesties have concerning Your activities of the last ten years, and could you tell us what You consider to be the duties Your Majesties should perform from now on?

RESPOSTA: I consider it an important dutv of ours to be close in our hearts to the disabled, the elderly and those who suffer from disaster, as well as those who are dedicating themselves to others or society as a whole. It is with such a thought that 
we visit welfare facilities and disaster areas. We cannot really describe what we have done in this regard as "activities." What we have tried to do as much as possible is to share our hearts with the people we meet at the facilities and disaster areas we visit.

(...)

In regard to social welfare, we face several challenges as we enter this era of an aging society. I hope that we will be able to strengthen the ties that bind $\underline{u s}$, and build a society in which all people can live with happy feelings through our incessant efforts to cope with various problems in this field. It is my hope that we can be of some help in providing moral support. [grifos meus]

Mais uma vez, na pergunta, o recurso da diferenciação (fragmentação) é utilizado, verificado pelo uso de iniciais maiúsculas nos pronomes, nos nomes de cerimônias e também nos títulos, como "Crown Prince" ("Kôtaishi"), reforçando a posição desse membro da Família Imperial, evidentemente um recurso das línguas ocidentais para demonstrar esse tipo de diferenciação.

$\mathrm{Na}$ resposta, no primeiro parágrafo, o uso de "duty of ours" e "our hearts" pode ser entendido como uma simbolização da unidade (unificação), estratégia que pode ser compreendida como uma forma de se representar diversos em um só, no caso indicando que os desejos da população e do Imperador devem andar juntos. No original, o Imperador utiliza o pronome pessoal "watakushidomo", equivalente a "we" (nós), além do verbo "suru" na forma "shiyô", significando "façamos" ("... otozureta shisetsu ya hisaichi de atta hitobito to sukoshi demo kokoro wo tomo ni shiyô to tsutomete kimashita"). Essa estratégia permite uma unificação do povo, fazendo com que a figura de seu representante seja reforçada. Além disso, o Imperador mais uma vez se refere aos membros de sua família como tendo todos os mesmos desejos que ele, e, portanto, utiliza a estratégia da universalização (legitimação) nas duas últimas orações do primeiro parágrafo.

No segundo parágrafo, verificamos o recurso da simbolização da unidade (unificação) mais uma vez, principalmente através dos pronomes utilizados, como "we", "us" e "our" O Imperador convida a população para junto com ele lutar por uma causa, unificando todos em torno de um desejo. Interessante observar que no original, o Imperador utiliza keigo ("kitaishite orimasu"), colocando-se em uma posição "inferior", de quem faz um apelo, o que passa credibilidade (“... minna ga shiawasena kimochi ni nareru yôna shakai wo kizuite iku koto wo kitaishite orimasu")

\subsection{Conferência de imprensa de 2009 , quando da comemoração de 20 anos de trono}

PERGUNTA: I believe that, over the past twenty years, Your Maiesty has, while considering how to interpret Your role as a "symbol", been seeking to put that role 
into action on a daily basis. Under the Constitution of Japan, it is clearly stated that "The Emperor shall be the symbol of the State and of the unity of the people", but it does not specify how that is to be achieved in practical terms. On the occasion of the Press Conference for Your Majesties' 50th Wedding Anniversarv. Your Maiestv stated, "How that symbolic role should be interpreted is a question never far from my mind, and to this day, I am still seeking an appropriate answer." How would you describe the nature of the "symbol" You have created during the Heisei Era? Sixtyfour years have passed since the end of the Second World War and, with three out of four Japanese people having been born since then, memories of that period are fading into the past. At the same time, in the years since Your Maiestv's accession to the throne. circumstances both in Japan and abroad have changed dramatically. Could Your Maiesties share with us your feelings and thoughts looking back on the Heisei Era so far, in Your Maiesty's position as a "Symbolic Emperor" and Her Majesty's as the Empress who supports that role?

RESPOSTA: As you say, the Constitution of Japan stipulates that "the Emperor shall be the symbol of the State and of the unity of the people". Over the past twentv vears. I have continuallv sought to interpret that symbolic role, bearing in mind both the long historv of the Imperial line and the well-being of the people. I have not however thought about any particular Heisei Era symbolism as the question suggests.

(...)

Unfortunately, subsequent events in the world did not follow a peaceful path. In 2001, the attacks on the World Trade Center and other targets caused the deaths of over 3,000 people. This triggered a war in Afghanistan, and subsequently another war started in Iraq as well, and to this day manv lives are being lost in these two countries as well as in Pakistan.

So the world todav cannot be said to be peaceful. but there is a more positive side in that the world has become more transparent and it has become possible for many more people to share factual information. For example, when abductions of Japanese citizens were being carried out by the North Koreans. not all the people in Japan were aware of these events, and as a result it is truly regrettable that the abductions continued, adding further to the number of victims. It is hard to imagine the anguish of the families of those involved.

(...)

I value highly the efforts made by all those engaged in agriculture, forestry and fisheries, who overcome many hardships by their imaginative solutions to the problems of maintaining their livelihoods. I look forward each year to meeting the awardees of the Emperor's Prize on the occasion of the annual Agriculture, Forestry and Fisheries Festival.

I am deeply concerned about people's welfare as Japan today becomes a rapidly ageing society at a time of severe economic conditions. It is encouraging to see, at a time like this, that there seems to be an increasing number of people who care about the elderly and those in need of nursing and who are making efforts to support them. I would like to see a societv where evervone supports one another.

I am delighted to see so many people celebrating this 20th year of the Heisei Era. I am grateful to them and take this opportunity to express my wishes for the peace and security of Japan and the health and happiness of the Japanese people. [grifos meus] 
A diferenciação (fragmentação), naturalmente, se apresenta mais uma vez na forma como a pergunta é formulada pelos jornalistas. Destaque para o não uso de maiúsculas em "Your Majesty's accession to the throne", diferente da forma como apareceu anteriormente (em 6.3). Mais uma vez, por alguma razão, as maiúsculas que marcam o nome de um evento institucional não foram utilizadas na tradução.

No primeiro parágrafo, Akihito inicia sua resposta citando a constituição, que afirma que o Imperador deve ser visto como símbolo do Estado e da união do povo. Essa passagem apresenta, portanto, a estratégia da simbolização da unidade (unificação), tornando Imperador e povo um só. E novamente Akihito faz uso da narrativização (legitimação) para justificar suas atitudes com base na história da Família Imperial, o que também o leva a eternalizar essa instituição (estratégia: eternalização; modo: reificação).

No segundo parágrafo, aparece o que Thompson chama de expurgo do outro (fragmentação), estratégia que visa criar um inimigo comum. No caso, a crítica principal é aos terroristas que realizaram os ataques de 2001 às Torres Gêmeas do World Trade Center, em Nova York. Esse inimigo, entretanto, não é citado de fato na resposta do Imperador, sendo entendido pela referência ao ocorrido. Da mesma forma, quando afirma que tais ataques iniciaram uma guerra no Afeganistão e no Iraque, Akihito não chega a citar os EUA como responsáveis. Não se comprometer com tais acusações é esperado por parte do Imperador, visto que ele é tido como símbolo da paz, além do fato de o Japão estar proibido pela Constituição de entrar em guerra. Assim, podemos perceber a estratégia do deslocamento (dissimulação), já que o Imperador cria estruturas como "the attacks (...) caused the deaths" (em japonês, "2001 nen Sekai Bôeki Sentâ Biiru nado ga ryokakki no totsunyû ni yori hakaisare, 3000 nin ijô no inochi ga ushinawaremashita"), omitindo os reais sujeitos de tais ataques, conscientemente ou não. Interessante observar que no original em japonês o Imperador faz uso da voz passiva, um recurso que serve para omitir os agentes da ação. Vale ressaltar aqui que a estratégia do expurgo do outro (fragmentação) ajuda a criar uma simbolização da unidade (unificação), uma vez que une todos em torno de um inimigo comum. Essa estratégia pode ser mais bem verificada a seguir.

O terceiro parágrafo se inicia com uma retomada do anterior, trazendo de novo o recurso de expurgo do outro (fragmentação), um pouco camuflado nesse momento, visto que nem no parágrafo anterior o Imperador nomeou os inimigos da paz, mas ele afirma que devido a eles o mundo atual não pode ser considerado pacífico. No entanto, essa estratégia de expurgo do outro vai se intensificar quando se trata da Coreia do Norte, inimigo do Japão de longa data. Akihito se orgulha de sempre ter conseguido manter boas relações desde o início de seu governo com todos os países que visitou em missões diplomáticas, mas Japão e Coreia do Norte nunca conseguiram se entender. Dadas essas circunstâncias, a criação 
desse inimigo do povo japonês fica mais clara do que os outros inimigos da paz sugeridos anteriormente. Importante ressaltar que, no original, o Imperador não cita especificamente a Coreia do Norte, referindo-se ao ocorrido como "rachi no mondai" ("a questão dos sequestros"). Entendo, assim, que para o povo japonês o ocorrido deve ser bastante conhecido por todos, não havendo necessidade de citar o nome do país responsável pelos sequestros, mas na tradução parece que tal citação se torna necessária, visto que talvez nem todos os leitores conheçam o evento. Além disso, como também já foi explicado, esse recurso de apontar um inimigo comum auxilia a criação de uma simbolização da unidade (unificação). $\mathrm{Na}$ última oração, o Imperador ainda faz uso da racionalização (legitimação), principalmente através da construção "it is hard to imagine", como se tratasse de uma dificuldade que qualquer um pudesse ter; em outras palavras, ele legitima esse sentimento através de uma cadeia lógica de raciocínio, buscando avivar nas pessoas um sentimento de amor pelos conterrâneos que foram vítimas dos ataques da Coreia do Norte, definindo-a, então, como inimigo comum dos japoneses. $\mathrm{O}$ uso da palavra "anguish" também reforça o mal que vem sendo feito aos japoneses por parte do país inimigo. Julgo importante ressaltar, entretanto, que o uso dessas estratégias não necessariamente são intencionais, mas, uma vez que se manifestam, são relevantes para este trabalho.

Nos parágrafos seguintes, encontramos em excesso o recurso de simbolização da unidade (unificação), um dos mais usados pelo Imperador, que procura sempre unir o seu povo em torno do mesmo pensamento e sentimento. A existência de um prêmio entregue pelo Imperador a agricultores, silvicultores e pescadores é um exemplo de unificação, proporcionada através do incentivo à população. E, por fim, a vontade de Akihito de que todos os japoneses ajudem uns aos outros comprova mais uma vez a utilização da simbolização da unidade, cuja utilização constante por parte do Imperador provavelmente se justifica devido à sua própria função no Estado, que é representar a união do povo japonês.

\section{Conclusões}

A partir da análise dessas quatro partes selecionadas das conferências de imprensa, procuro, então, justificar o aparecimento de cada um dos modos de operação da ideologia e das estratégias de construção simbólica que aparecem nas alocuções do Imperador do Japão.

O uso da legitimação ocorre em três momentos diferentes. O primeiro deles se mostra através da estratégia da racionalização, que aparece duas vezes e serve para legitimar sentimentos do Imperador, como a questão da política externa e do que ele sente a respeito dos ataques por parte dos norte-coreanos. A universalização serve, principalmente, quando Akihito fala em nome de toda a Família Imperial, 
pressupondo que seu desejo é também o desejo de todos os seus parentes, visto que reinam sob uma mesma Constituição. Finalmente, a narrativização serve como uma ferramenta de reforço para o que o Imperador diz, principalmente quando se refere à história dos imperadores do Japão. Seus exemplos geralmente remetem ao Imperador Shôwa, seu pai, supondo que ele sempre buscou a felicidade do povo.

No que diz respeito ao modo de operação da ideologia chamado de dissimulação, verificamos o uso de apenas duas estratégias. O deslocamento se limita a uma única ocorrência, que remete aos ataques terroristas, evitando nomear pessoas ou grupos. A eufemização, por sua vez, se mostra principalmente útil quando o Imperador parece procurar inocentar o Imperador Shôwa, eliminando uma possível culpa atribuída a ele devido à participação do Japão na II Guerra Mundial (ex.: "great difficulties continued for Emperor Showa"). Da mesma forma, quando se refere a outros imperadores, coloca a responsabilidade de seus atos na Constituição.

Quanto ao modo de unificação, verificamos o uso da padronização (ou estandardização) em todos os textos analisados, embora eu não tenha comentado essa estratégia no capítulo pertinente à análise, visto que se trata de um recurso presente em todas as alocuções realizadas pelo Imperador. Trata-se do uso da língua japonesa padrão, estratégia que serve de união do povo, diferente do Imperador Shôwa, que utilizava o japonês arcaico, pouco entendido por grande parte da população, incluindo termos específicos utilizados apenas para o Imperador (ex.: pronome pessoal "chin", utilizado por Hirohito quando se referia a si mesmo). Tão relevante quanto a padronização é a simbolização da unidade, recurso de maior ocorrência, justificada pela própria função do Imperador, que é servir de símbolo do Estado e da união do povo. Verifica-se também o uso da simbolização da unidade quando se trata de possíveis inimigos comuns do povo japonês, como os norte-coreanos (não citados explicitamente no original em japonês, mas subentendido no discurso).

A fragmentação se mostra por meio de duas estratégias. A diferenciação pode ser verificada principalmente por parte dos jornalistas, quando fazem as perguntas na conferência de imprensa, uma vez que se utilizam de termos como "His Majesty" ("Heika" ou “Ten'nô Heika"), ou seja, referem-se aos membros da Família Imperial por seus títulos e não por seus nomes. Também pode-se perceber essa estratégia no uso do keigo por parte dos jornalistas, respondendo o Imperador apenas em linguagem formal, sem necessariamente utilizar keigo (a não ser quando conveniente), o que fortalece sua posição. A utilização da estratégia de expurgo do outro, por sua vez, se dá em duas situações específicas: quando o Imperador fala dos terroristas e dos norte-americanos, sem nomeá-los, e depois quando trata dos norte-coreanos, criticando-os abertamente (mais uma vez cabe aqui ressaltar que no original Akihito não cita diretamente os norte-coreanos). O Imperador os apresenta como ameaças à paz mundial e, indiretamente, convoca o povo a não aprovar suas atitudes. 
Quanto ao último modo de operação da ideologia, a reificação, verificamos o uso da estratégia chamada de eternalização, que ocorre principalmente quando Akihito parece querer reforçar o status da Família Imperial, referindo-se à longa história de reinado e remetendo a um futuro em que continuarão cumprindo seu papel. A estratégia da passivização também aparece, no original japonês, quando se refere ao ataque às Torres Gêmeas, omitindo os agentes reais da ação e colocando como sujeitos oracionais as vítimas do atentado ("3000 nin ijô no inochi ga ushinawaremashita").

A partir da interpretação dos resultados obtidos, pode-se então confirmar a presença da ideologia por meio de certas estratégias típicas de construção simbólica, produtoras de sentido, o que garante a relação de dominação entre instituição imperial e povo japonês. Através dos modos de operação da ideologia, podemos, portanto, verificar de que forma certas construções linguísticas (e mesmo outros dispositivos não linguísticos) podem funcionar como mantedoras de relações de dominação e subordinação.

Encerro este trabalho informando que não procurei, enquanto pesquisador, fazer nenhuma crítica negativa ao Imperador e à sua função, mas apenas mostrar como é possível percebermos questões ideológicas em suas alocuções.

\section{Referências}

BIRTH OF THE CONSTITUTION OF JAPAN. The Constitution of Japan. Disponível em: $<$ http://www.ndl.go.jp/constitution/e/etc/c01.html $>$. Acesso em 29 mar. 2012.

BIRTH OF THE CONSTITUTION OF JAPAN. The Constitution of the Empire of Japan. Disponível em: $<$ http://www.ndl.go.jp/constitution/e/etc/c02.html >. Acesso em 29 mar. 2012.

FAIRCLOUGH, Norman. Teoria Social do Discurso. In: FAIRCLOUGH, Norman. Discurso e Mudança Social. Brasília: Ed. da UnB, 2001. P. 89-131.

IMPERIAL HOUSEHOLD AGENCY (KUNAICHO). Disponível em: $<$ http://www.kunaicho. go.jp>. Acesso em 29 mar. 2012.

NAKAMURA, Masanori. The Japanese Monarchy: Ambassador Joseph Grew and the Making of the 'Symbol Emperor System', 1931-1991. Tradução Herbert P. Bix; Jonathan Baker-Bates; Derek Bowen. Nova York: M. E. Sharpe, 1992.

RESENDE, Viviane; RAMALHO, Viviane. Discurso e Ideologia. In: RESENDE, Viviane; RAMALHO, Viviane. Análise de Discurso Crítica. São Paulo: Contexto, 2006. P. 47-54.

THOMPSON, John B. O Conceito de Ideologia. In: THOMPSON, John B. Ideologia e Cultura Moderna: Teoria Social Crítica na Era dos Meios de Comunicação de Massa. Petrópolis: Vozes, 2002. P. 43-99. 